\title{
PENTINGNYA PERTOLONGAN PERSALINAN OLEH TENAGA KESEHATAN DI FASILITAS PELAYANAN KESEHATAN DI KAMPUNG DAPUR 6 KELURAHAN SEMBULANG KECAMATAN GALANG KOTA BATAM
}

\author{
Aminah Aatinaa Adhyatma ${ }^{1}$, Nita Agustin ${ }^{2}$, Rana Prasenja Sahara ${ }^{3}$ \\ STIKes Awal Bros Batam \\ Program Studi D-III Kebidanan STIKes Awal Bros Batam \\ 1atina.adhyatma1901@gmail.com
}

\begin{abstract}
The Maternal Mortality Rate is an indicator to see the degree of women's welfare and the targets that have been determined in the development goals of Sustainable Development Goals (SDGs). Delivery by health personnel in the community is still very low compared to the expected target. The selection of birth attendants and health facilities is a factor that determines the implementation of a safe delivery process. PKM activities were held on March 19, 2020 in Kampung Dapur 6, Sembulang Village, Galang District, Batam City involving 32 participants. This community service aims to provide knowledge and insight to the community about the importance of childbirth by health workers in health service facilities. This activity was carried out with counseling and discussions involving pregnant women and health cadres who were in Kampung Dapur 6, Sembulang Village, Galang District, Batam City. The results obtained from community service are that the community understands the importance of giving birth to be assisted by health workers and in health service facilities. Knowledge of pregnant women and health cadres has increased, cadres are able to motivate mothers to give birth with health workers. It is hoped that this program of activity can be used as a pilot activity for other regional interventions, through cadres and midwives who are in the working area of the Galang Health Center.
\end{abstract}

Keywords: Childbirth in health facilities, Health Workers, Health Counseling

\begin{abstract}
ABSTRAK
Angka Kematian Ibu merupakan salah satu indikator untuk melihat derajat kesejahteraan perempuan dan target yang telah ditentukan dalam tujuan pembangunan Suistenaible Development Goals (SDGs). Pertolongan persalinan oleh tenaga kesehatan di masyarakat masih sangat rendah dibandingkan dengan target yang diharapkan. Pemilihan penolong persalinan dan fasilitas kesehatan merupakan faktor yang menentukan terlaksananya proses persalinan yang aman. Kegiatan PKM dilaksanakan pada 19 Maret 2020 di Kampung Dapur 6 Kelurahan Sembulang Kecamatan Galang Kota Batam melibatkan 32 orang peserta. Pengabdian masyarakat ini bertujuan untuk memberikan pengetahuan dan wawasan kepada masyarakat tentang pentingnya persalinan oleh tenaga kesehatan di fasilitas pelayanan kesehatan. Kegiatan ini dilakukan dengan penyuluhan dan diskusi yang melibatkan ibu hamil serta kader kesehatan yang berada di Kampung Dapur 6 Kelurahan Sembulang Kecamatan Galang Kota Batam. Hasil yang didapatkan dari pengabdian masyarakat adalah masyarakat memahami tentang pentingnya ibu bersalin ditolong oleh tenaga kesehatan dan di fasilitas pelayanan kesehatan. Pengetahuan ibu hamil dan kader kesehatan meningkat, kader mampu memberikan motivasi kepada ibu untuk melakukan persalinan dengan tenaga kesehatan. Program kegiatan ini diharapkan dapat dijadikan sebagai kegiatan percontohan intervensi daerah lain, melalui kader dan bidan yang berada di wilayah kerja Puskesmas Galang.
\end{abstract}

Keywords: Persalinan di Fasilitas Kesehatan, Tenaga Kesehatan, Penyuluhan kesehatan. 


\section{PENDAHULUAN}

Penurunan AKI dan AKB di daerah terpencil belum bisa seperti yang diharapkan pemerintah, karena di masyarakat terpencil pada umumnya mereka masih banyak yang belum bersalin di fasilitas kesehatan . beberapa faktor yang menjadi penyebab masyarakat memilih bersalin di fasilitas non nakes yaitu masyarakat terpencil yang merupakan daerah pegunungan dan jangkauan yang sulit, latar belakang pendidikan yang rendah, sosial ekonomi yang lemah, dan akses layanan kesehatan yang kurang baik, sehingga masih banyak ibu hamil yang memilih bersalin di tenaga non kesehatan atau dukun. Selain karena faktor geografis sulitnya akses kesehatan, pendidikan dan lainnya. Faktor dukungan keluarga misalnya, apabila keluarga masih banyak mempercayai halhal yang berbau tahayul dan menurunya rasa gotong-royong atau kebersamaan diantara keluarga, hal ini bisa mempengaruhi keputusan keluarga dalam memilih pertolongan persalinan di pelayanan kesehatan, serta hal ini dapat menjadi hal yang perlu diselesaikan karena bisa mempengaruhi ibu bersalin dalam memilih pertolongan persalinannya di tenaga kesehatan.

Pemerintah membuat suatu upaya dalam mendukung tercapainya target menurunkan AKI, diantaranya membuat beberapa kemudahan bagi masyarakat dalam mencapai pelayanan fasilitas kesehatan dengan cara menambah puskesmas baru di daerah-daerah terpencil dan menetapkan tiap satu desa minimal satu bidan yang bertempat tinggal di desa tersebut, sehingga MDGs persalinan oleh tenaga kesehatan bisa tercapai 100 persen, yang pada akhirnya AKI dan AKB dapat diturunkan. (Sumardi dkk, 2011).

Angka Kematian Ibu untuk Kota Batam tahun 2017 sebesar 105/100.000 kelahiran hidup, sedangkan Angka Kematian Bayi sebesar 5,7/1.000 kelahiran hidup. Angka Kematian Ibu merupakan salah satu indikator untuk melihat derajat kesejahteraan perempuan dan target yang telah ditentukan dalam tujuan pembangunan Sustainable Development Goals (SDGs) maka dari itu upaya untuk mewujudkan target tersebut masih membutuhkan komitmen dan usaha keras yang terus menerus (Dinkes Kota Batam, 2019).

Tingginya persalinan yang ditolong oleh dukun merupakan salah satu penyebab rendahnya cakupan pertolongan persalinan oleh tenaga kesehatan. Berdasarkan data tahun 2019 didapatkan, cakupan persalinan di fasilitas kesehatan di Pulau Galang Kota Batam belum mencapai target. Hal ini dipengaruhi oleh kentalnya sosial budaya, sehingga masyarakat tabu dan memilih tenaga non medis sebagai penolong persalinan. Berdasarkan laporan Dinas Kesehatan Kota Batam, cakupan pertolongan persalinan di fasilitas kesehatan masih rendah. Rata-rata masyarakat setempat memilih bersalin di rumah baik oleh nakes maupun non nakes. (Dinkes Kepri, 2016).

Berdasarkan hasil survey lapangan, cakupan persalinan tenaga kesehatan di fasilitas pelayanan kesehatan masih belum mencapai target. sebagian masyarakat di Desa Dapur 6 Kelurahan Sembulang Kecamatan Galang, lebih memilih tenaga non kesehatan atau dukun sebagai penolong persalinan di rumah. Beberapa alasan persalinan ditolong oleh dukun yaitu adanya kepercayaan, budaya melahirkan dirumah, serta transportasi yang tidak memadai untuk mencapai tempat pelayanan kesehatan. Masyarakat percaya bahwa dukun memiliki kemampuan menolong persalinan yang diwariskan secara turun temurun dan dukun memberikan pengalaman-pengalaman kepada ibu yang melahirkan untuk siap menjadi orang tua. Selain itu, dari segi biaya, masyarakat percaya biaya bersalin di dukun lebih murah. Sebagian besar masyarakat juga merasakan kenyamanan jika bersalin dengan dukun karena selalu melakukan pendampingan dimulai ibu merasakan mules, selama bersalin dan setelah bersalin hingga mengajarkan cara merawat bayi seperti memandikan bayi. Begitu banyak pelayanan yang diberikan oleh dukun dengan cara tradisional yang dapat membuat sebagian besar masyarakat percaya keberadaannya dalam membantu proses persalinan. Hal ini menunjukan masyarakat belum mengetahui risiko yang mungkin dapat timbul akibat bersalin dirumah tanpa dilengkapi dengan peralatan yang memadai dan ditolong oleh tenaga non kesehatan.

Berdasarkan latar belakang tersebut penulis tertarik untuk melakukan pengabdian masyarakat sebagai upaya mengurangi Angka Kematian Ibu (AKI) dan Angka Kematian Bayi (AKB), dan menambah wawasan masyarakat mengenai pentingnya bersalin dengan tenaga kesehatan dan di fasilitas pelayanan kesehatan guna mencegah komplikasi/penyulit yang memerlukan tindakan segera.

\section{METODE}

Kegiatan pelaksanaan PKM dilaksanakan pada hari Kamis tanggal 19 Maret 2020 di Kampung Dapur 6 Kelurahan Sembulang Kecamatan Galang Kota Batam. Materi yang disajikan pada pengabdian masyarakat ini adalah tentang pentingya pertolongan persalinan oleh tenaga kesehatan di fasilitas pelayanan kesehatan.

Metode kegiatan pengabdian kepada masyarakat ini adalah memberikan penyuluhan dan diskusi. Adapun sasaran dalam kegiatan pengabdian 
masyarakat ini adalah oleh ibu hamil dan kader kesehatan di Kampung Dapur 6 Kelurahan Sembulang Kecamatan Galang Kota Batam yang seluruhnya berjumlah 32 orang. Adapun tugas dari masing - masing anggota tim pengabdian kepada masyarakat ini, antara lain :

\section{Moderator : Anggota 1 : Nita Agustin}

Tugas

a. Melakukan presensi

b. Membuka dan menutup acara

c. Memperkenalkan diri

d. Menjelaskan tata tertib dan alur pelaksanaan kegiatan pengabdian masyarakat

e. Memimpin diskusi, memandu jalannya kegiatan

f. Menyimpulkan kegiatan di akhir penyuluhan

2. Pemateri : Aminah Aatinaa Adhyatma Tugas

a. Menyajikan materi penyuluhan

b. Menggali pengetahuan peserta penyuluhan mengenai topik presentasi

c. Memberikan pengertian tentang hal - hal yang tidak dipahami oleh peserta

d. Menjalin kerja sama dengan fasilitator dalam kegiatan penyuluhan

e. Membentuk kelompok binaan tim kader kesehatan dan ibu hamil dalam upaya pengawasan dan pendampingan persalinan

\section{Observer : Anggota 2 : Rana Prasenja} Tugas

a. Mengamati jalannya kegiatan

b. Mencatat tanggapan yang dikemukakan peserta

c. Membuat laporan hasil kegiatan

d. Mengevaluasi kegiatan

Adapun tujuan dan target capaian dari pelaksanaan pengabdian kepada masyarakat ini adalah :

1. Keterkaitan dengan mahasiswa dan staf dosen yang terlibat pengabdian kepada masyarakat

a. Mengaplikasikan ilmu yang diperoleh tentang persalinan

b. Sebagai pengalaman nyata dalam melakukan kegiatan penyuluhan tentang pertolongan persalinan oleh tenaga kesehatan di fasilitas pelayanan kesehatan.

2. Keterkaitan dengan perguruan tinggi

a. Bentuk Implementasi Tri Dharma Perguruan Tinggi melalui pengembangan ilmu kebidanan

b. Menemukan permasalahan nyata dalam pertolongan persalinan serta penentuan tempat bersalin yang aman sehingga dapat dilakukan perbaikan melalui pengembangan penelitian dan pengabdian masyarakat selanjutnya. c. Mengimplementasikan teori dan ilmu untuk kepentingan masyakarakat

3. Keterkaitan dengan masyarakat

a. Ibu hamil dan kader kesehatan memahami tentang pentingnya pertolongan persalinan oleh tenaga kesehatan di fasilitas pelayanan kesehatan.

b. Dapat memotivasi kader kesehatan agar meningkatkan kemampuannya dalam melaksanakan peranannya serta dapat membantu petugas medis dalam pelayanan kesehatan ibu dan anak.

c. Dapat memotivasi ibu hamil dan keluarga, kader kesehatan serta tokoh masyarakat untuk memanfaatkan fasilitas pelayanan kesehatan yang telah tersedia di wilayah setempat.

\section{HASIL DAN IMPLIKASI}

Kegiatan pengabdian kepada masyarakat yang dilaksanakan di Kampung Dapur 6 Kelurahan Sembulang Kecamatan Galang, diawali dengan meninjau lokasi pengabdian masyarakat serta pendekatan kepada pihak puskesmas Galang serta tokoh masyarakat setempat. Ketua pelaksana mengajukan ijin penggunaan lahan pengabdian masyarakat serta rapat koordinasi dengan pihak-pihak terkait yang dilaksanakan pada tanggal 16 Maret 2020 di ruang pertemuan Kecamatan Galang. Rapat diawali dengan pembukaan dan pengarahan dari Kepala LPPM STIKes Awal Bros Batam. Selanjutnya, pengarahan dari ketua pelaksana mengenai mekanisme pelaksanaan kegiatan pengabdian masyarakat di Kampung Dapur 6 Kelurahan Sembulang Kecamatan Galang, Koordinasi dengan kader kesehatan dan bidan praktik mandiri setempat dilaksanakan pada tanggal 17 Maret 2020 .

Pelaksanaan kegiatan penyuluhan di Kampung Dapur 6 Kelurahan Sembulang Kecamatan Galang Kota Batam Kota Batam berjalan dengan lancar. Peserta yang mengukuti kegiatan penyuluhan berjumlah 32 orang. Kegiatan diawali dengan pemberian pre-test untuk mengukur pengetahuan awal tentang Pentingnya pertolongan persalinan di tenaga kesehatan. Penyuluhan dilaksanakan dengan membagikan leaflet sebagai media penyuluhan. Penyampaian materi dilakukan dengan gambar-gambar yang menarik serta diskusi sehingga peserta menjadi antusias dalam mendengarkan penjelasan yang diberikan. Pemahaman peserta setelah penyuluhan diukur dengan memberikan post-test. Soal post-test yang diberikan sama dengan soal pre-test. Dari 32 orang peserta penyuluhan, pada nilai pre-test didapatkan hasil pengetahuan baik sebanyak 8 orang dan pengetahuan cukup 24 orang, 
sementara hasil post-test yang memiliki pengetahuan baik sebanyak 28 orang dan yang memiliki pengetahuan cukup sebanyak 4 orang. Hal ini mengindikasikan bahwa pemberian penyuluhan mengenai pentingnya pertolongan persalinan oleh tenaga kesehatan sangat mempengaruhi peningkatan pengetahuan peserta mengenai materi tersebut.

Pengetahuan merupakan hasil dari tahu, dan hal ini terjadi setelah orang melakukan penginderaan terhadap suatu obyek tertentu dalam membentuk tindakan seseorang suatu objek tertentu melalui panca indera manusia yaitu indera penglihatan, pendengaran, penciuman rasa dan raba. Dengan adanya pengetahuan yang baik maka akan terbentuk tindakan seseorang dan perilaku yang didasari oleh pengetahuan yang baik akan lebih langgeng daripada perilaku yang tidak didasari oleh pengetahuan, sehingga aspek pengetahuan ini merupakan hal yang sangat berpengaruh dan penting karena pengetahuan akan membentuk keyakinan tertentu sehingga seseorang dapat berperilaku sesuai dengan keyakinannya.

Banyak faktor-faktor yang mempengaruhi pengetahuan antara lain sosial ekonomi, budaya, pendidikan dan pengalaman. Pengetahuan seseorang didukung oleh lingkungan sosialnya, jika ekonomi baik maka pendidikan seseorang juga baik sehingga memiliki pengetahuan yang baik juga (Notatmodjo, 2010). Semakin tinggi pendidikan maka akan semakin mudah menerima hal-hal baru dan mudah menyesuaikan. Selain itu informasi yang baru didapat akan disaring sesuai dengan budaya dan keyakinananya yang ada sehingga budaya sangat berpengaruh terhadap tingkat pengetahuan seseorang. Umur dan pendidikan seseorang juga akan mempengaruhi terhadap pengalaman seseorang sehingga akan lebih matang berpikir dan siap menerima informasi. Ketika seseorang telah siap dan memiliki sikap positive secara otomatis akan timbul motivasi atau keinginan berperilaku terhadap hal yang positif sehingga sangat memungkinkan ibu mau berperilaku sesuai dengan apa yang diketahuinya dan yang diyakininya.

Persalinan adalah Proses dimana bayi, plasenta dan selaput ketuban keluar dari uterus ibu. Persalinan dianggap normal jika prosesnya terjadi pada usia kehamilan cukup bulan tanpa disertai penyulit (Indrayani, 2016). Penolong persalinan dan tempat/ fasilitas persalinan saling berkaitan erat. Penolong persalinan dan fasilitas pelayanan kesehatan sangat berpengaruh terhadap penurunan angka kematian ibu dan bayi karena dapat mendeteksi lebih dini kemungkinan komplikasi terjadinya resiko kesakitan dan kematian pada ibu dan bayi. Persalinan yang aman adalah persalinan yang dilaksanakan di fasilitas kesehatan oleh tenaga kesehatan yang terampil. Sedangkan pertolongan persalinan oleh tenaga kesehatan yang dimaksud adalah tenaga kesehatan yang professional yang telah melalui pendidikan formal seperti dokter, bidan dan tenaga para medis lainnya yang sudah terlatih dan terampil dalam membantu persalinan, sehingga keselamatan ibu dan bayi lebih terjamin. Apabila terdapat masalah atau komplikasi yang terjadi, akan cepat diketahui dan segera dapat ditolong atau dirujuk ke Puskesmas atau Rumah Sakit. Persalinan yang ditolong oleh tenaga kesehatan menggunakan peralatan yang aman, bersih, dan steril sehingga mencegah terjadinya infeksi dan bahaya kesehatan lainnya.

Banyaknya faktor yang mempengaruhi masyarakat yang bersalin di tenaga non kesehatan yaitu terbatasnya ekonomi terutama bagi masyarakat terpencil sehingga masyarakat tidak memilih tenaga kesehatan sebagai penolong persalinan. Pendidikan, pekerjaan, pengetahuan, dukungan keluarga, transporasi, keterjangkauan terhadap pelayanan kesehatan, serta sosial budaya merupakan faktorfaktor yang mempengaruhi ibu dalam memilih penolong persalinan baik di tenaga kesehatan maupun di dukun.

Masyarakat di kampung dapur 6 menganggap kehamilan dan persalinan merupakan kodratnya seorang perempuan yang tidak begitu dipermasalahkan dalam artian proses alamiah ini akan terjadi dengan sendirinya, melahirkan oleh dukun maupun bidan tergantung situasi dan kondisi saat ingin bersalin serta transportasi yang tersedia, masyarakat menganggap tidak memerlukan persiapan dari jauh-jauh hari. Masyarakat merasa jika bersalin dirumah lebih nyaman dan jika terjadi bahaya itu merupakan takdir.

Beberapa alasan persalinan ditolong oleh tenaga non nakes atau dukun yang dikemukakan oleh masyarakat yaitu adanya kepercayaan-kepercayaan, budaya melahirkan dirumah, serta transportasi yang tidak memadai untuk mencapai tempat pelayanan kesehatan. Masyarakat percaya bahwa dukun memiliki kemampuan menolong persalinan yang diwariskan secara turun temurun. Dukun juga memberikan pengalaman-pengalaman kepada ibu yang melahirkan untuk siap menjadi orang tua. Selain itu, dari segi biaya, masyarakat percaya biaya bersalin di dukun lebih murah. Sebagian besar masyarakat juga merasakan nyaman ika bersalin dengan dukun karena selalu melakukan pendampingan dimulai ibu merasakan mules, selama bersalin dan setelah bersalin hingga mengajarkan cara merawat bayi seperti memandikan bayi. Begitu banyak pelayanan yang diberikan oleh dukun dengan cara tradisional yang dapat membuat sebagian besar masyarakat percaya keberadaannya dalam membantu proses persalinan. Hal ini menunjukan masyarakat belum mengetahui risiko yang mungkin dapat timbul akibat bersalin dirumah tanpa dilengkapi dengan peralatan 
yang memadai dan ditolong oleh tenaga non kesehatan.

Melalui pengabdian masyarakat ini, masyarakat dapur 6 Kelurahan Sembulang memahami pentingnya pertolongan persalinan oleh tenaga kesehatan dan di fasilitas kesehatan yang tersedia. Kepala desa dan kader kesehatan telah berinisiatif untuk mendata seluruh ibu hamil terutama ibu hamil yang telah memasuki trimester ke-III, untuk diberikan edukasi dan proses pendampingan oleh kader dengan membentuk kelompok binaan, dimana kader kesehatan bertugas untuk melaporkan kepada bidan apabila ada ibu hamil, membantu ibu hamil mengakses layanan kesehatan terutama apabila diperlukan rujukan, memotivasi ibu hamil untuk bersalin di tenaga kesehatan dan di fasilitas pelayanan kesehatan. Diharapkan kader kesehatan dapat melaksanakan perannya dengan baik, serta mampu berkoordinasi dengan bidan. Diharapkan semua masyarakat dapur 6 kelurahan sembulang dapat meningkatkan kewaspadaan masyarakat untuk mendukung ibu bersalin di tenaga kesehatan dan di fasilitas kesehatan yang telah tersedia.

Luaran yang diharapkan melalui kegiatan PKM ini adalah sebagai berikut :

1. Meningkatnya jumlah pertolongan persalinan oleh tenaga kesehatan di fasilitas pelayanan kesehatan Kampung Dapur 6 Kelurahan Sembulang Kecamatan Galang

2. Artikel ilmiah yang akan dimuat pada jurnal nasional

3. Laporan pengabdian masyarakat

\section{SIMPULAN}

1. Kegiatan pengabdian masyarakat dapat diselengarakan dengan baik dan berjalan lancar sesuai dengan jadwal dan mekanisme pelaksanaan kegiatan yang telah disusun oleh tim pengabdian masyarakat serta disepakati oleh Puskemas Galang, Kelurahan Sembulang dan Kecamatan Galang.

2. Telah terbentuknya kelompok binaan dalam upaya persiapan persalinan oleh kader kesehatan dan ibu hamil di Kampung dapur 6 Kelurahan Sembulang Kecamatan Galang dalam pengawasan Puskesmas Galang.

3. Penyuluhan dan diskusi tentang pentingnya persalinan oleh tenaga kesehatan di fasilitas pelayanan kesehatan telah dilakukan dengan hasil memuaskan.

\section{SARAN}

1. Ibu hamil hendaknya dapat menambah wawasan dan pengetahuan tentang pentingnya pertolongan persalinan di fasilitas pelayanan kesehatan.

2. Kader Kesehatan hendaknya dapat mengaplikasikan ilmu dan wawasan yang telah diberikan atau dipaparkan oleh Tim Pengabdian Masyarakat STIKes Awal Bros Batam serta memotivasi ibu hamil dan keluarga dalam hal persiapan persalinan.

3. Puskesmas/ Bidan setempat hendaknya dapat melakukan monitoring secara berkala terhadap kelompok binaan kader kesehatan dan ibu hamil.

\section{DAFTAR PUSTAKA}

DepKes Kepri. (2016). Profil Kesehatan Provinsi Kepulauan Riau. Tanjung Pinang: Departemen Kesehatan Provinsi Kepulauan Riau. Diakses pada tanggal 2 Maret 2020 pada laman http//depkes.go.id/profil/kes/provinsi/kepri/2016 .pdf.

Direktorat Promosi Kesehatan dan Pemberdayaan Masyarakat Kementerian Kesehatan. 2012. Persalinan Ditolong Oleh Tenaga Kesehatan.

Direktorat Jenderal Bina Kesehatan Masyarakat. 2015. Kesehatan Reproduksi dan Seksual Bagi Calon Pengantin.Jakarta : Kemenkes RI

Notoatmodjo, S., 2010, Promosi Kesehatan dan Perilaku Kesehatan, Jakarta : Rineka Cipta

Prawirohardjo, Sarwono, 2011. Ilmu Kebidanan . Jakarta : Bina Pustaka Sarwono Prawirohardjo.

Rohani, dkk. 2016 . Asuhan Kebidanan Pada Masa Persalinan. Jakarta : Salemba Medika.

Sumardi, Rijadi, Busroni, Setyowati, Muhawarman, 2011. Jampersal Solusi Persalinan, Jakarta : Medika 